\title{
UNA VISIÓN SOBRE EL TRATAMIENTO LEGAL DE LA PUBLICIDAD SEXISTA EN EL PERÚ
}

\author{
AN INSIGHT ON THE LEGAL TREATMENT \\ OF SEXIST ADVERTISING IN PERU
}

Gisela Hortencia Vidal Cabeza de Tarazona ${ }^{1}$

\section{RESUMEN}

En base al análisis de tres resoluciones expedidas por la Comisión de Represión de la Competencia Desleal del Instituto Nacional de Defensa de la Competencia y Protección de la Propiedad Intelectual (INDECOPI), el presente artículo presenta una visión sobre el tratamiento legal aplicable a la publicidad denunciada como atentatoria a los derechos de dignidad y no discriminación contra la mujer (publicidad sexista) haciendo una comparación con el ordenamiento jurídico vigente.

\section{Palabras Clave}

Principio de legalidad, Principio de adecuación social, publicidad sexista, mujer, publicidad

\section{ABSTRACT}

Based on the analysis of three decisions issued by the Commission of Repression of Unfair Competition of the National Institute for the Defense of Competition and Intellectual Property (INDECOPI), this article provides an insight on the legal treatment applicable to the challenged advertising as an infringement of the rights of dignity and non-discrimination against women (sexist advertising) making a comparison with the current legal system.

\section{Keywords}

Principle of legality, social adequacy principle, sexist advertising, woman, advertising

\section{INTRODUCCIÓN}

Sin duda alguna, las marcas cumplen un rol muy importante en el mundo comercial porque permiten que los productos y servicios se distingan de otros en el mercado. No obstante ello, para lograr su posicionamiento, es necesario además, realizar un proceso comunicativo en donde brindar una mayor información sobre el producto o servicio, así como el uso de la persuasión, resultan ser elementos determinantes que pueden influir en la captación y decisión de compra del consumidor. Este proceso comunicativo se denomina publicidad comercial. El fenómeno de la publicidad, por su gran impacto en la sociedad y su influencia en la conducta de los consumidores, puede causar situaciones controvertidas, donde incluso los valores y los derechos fundamentales de las personas pueden verse afectados ${ }^{2}$. Por tal motivo, esta actividad se encuentra regulada por normas administrativas de carácter nacional interno, las mismas que no solo regulan la forma

1 Abogada, Docente Ordinaria de la Facultad de Derecho de la UNIFÉ. Coordinadora del Instituto de la Familia de la Facultad de Derecho de la misma universidad.

2 En los últimos años, se han divulgado a través de los medios publicidad que contiene mensajes que enaltecen la noción de 
sino también el contenido del anuncio. En tal sentido, todo anuncio publicitario deberá cumplir determinados principios como: el de legalidad, adecuación social (previsto en el actual Decreto Legislativo 1044 - Ley de Represión de la Competencia Desleal), no discriminación, veracidad, decencia, lealtad, autenticidad, libre y leal competencia y no denigración (previstos en el actual Código del Consejo Nacional de Autorregulación Publicitaria - CONAR), en la publicidad ${ }^{3}$. El objetivo radica en que la difusión de la publicidad comercial no afecte los derechos de los agentes en el mercado (consumidores y competidores), pero sobre todo no debería afectar los derechos fundamentales de las personas, como el de un trato digno, no discriminatorio, que no sea ofensivo sino igualitario. En los años 2006-2008 la Comisión de Defensa de la Competencia del Instituto Nacional de Defensa de la Competencia y de la Protección de la Propiedad Intelectual - INDECOPI, como primera instancia administrativa, admitió a trámite denuncias interpuestas por parte de la ONG DEMUS Estudio para la Defensa y los Derechos de la Mujer, por cuanto dicha entidad consideró que determinadas empresas anunciantes estaban infringiendo con su publicidad el principio de legalidad, por considerar que sus respectivos anuncios publicitarios estarían ofendiendo la dignidad de la mujer. En uno de los casos, la entidad administrativa resolvió declarando fundada la denuncia interpuesta; sin embargo, la mayoría fueron declarados infundados. Ante esta realidad, cabe preguntarnos si realmente ¿estábamos o no frente a una publicidad de carácter sexista que denigra la dignidad de la mujer?; y si así fuera, ¿por qué las denuncias interpuestas fueron declaradas infundadas por la autoridad? Es por esta razón, que nos permitimos elaborar el presente trabajo con la intención de descubrir si entre las denuncias interpuestas por DEMUS estábamos o no ante una publicidad sexista, que ofende la dignidad de la mujer y encontrar las razones por las cuales sus denuncias fueron desestimadas, toda vez que esperamos que la valoración de la mujer, premisa categórica para su protección y defensa declarada por la Convención de la $\mathrm{CEDAW}^{4}$, no tenga una valoración distinta para el Estado y que la sociedad civil mantenga una visión clara y no dispersa en cuanto opiniones.

\section{LA PUBLICIDAD, LOS VALORES Y SU IMPACTO EN LA CONDUCTA DEL CONSUMIDOR}

Según el Diccionario de la Real Academia de la Lengua Española, el término "publicidad", hace referencia a la cualidad o estado público, también se refiere al conjunto de medios que se emplea para divulgar o extender la noticia de las cosas o de los hechos; así como a la divulgación de noticias o anuncios de carácter comercial para atraer a posibles compradores, espectadores, usuarios, etc.

lo masculino denigrando al sexo opuesto. Su contenido sociológico en cuanto a roles sexuales con asignaciones peyorativas de género es notable. Dicho esto, creemos que la interpretación de los anuncios de publicidad que signifiquen, denoten o connoten distingos entre sexo, raza, condición socioeconómica y otros status, debe ser muy cuidadosa.

3 Si bien el Principio de Legalidad, y el de no discriminación estuvieron previstos en el Decreto Legislativo 691 -Normas de Publicidad en Defensa del Consumidor-, actualmente los Principios de Legalidad y de Adecuación Social están previstos en el Decreto Legislativo 1044. Los demás principios podemos encontrarlos en el Código del Consejo Nacional de Autorregulación Publicitaria (CONAR), que si bien sus resoluciones no forman parte del presente trabajo, es importante señalar que están previstos en dicho código y deben ser cumplidos por los anunciantes.

Asimismo, es necesario mencionar que el Consejo Nacional de Autorregulación Publicitaria -CONAR, (organismo autónomo de iniciativa privada) - mediante la aplicación de su Código de Ética Publicitaria, tiene como finalidad instaurar la cultura de la autorregulación en dicha industria. Entre sus funciones está la de fomentar el desarrollo de la industria publicitaria, mediante el uso y la práctica de la publicidad de acuerdo con un conjunto de principios básicos denominados de legalidad, decencia, veracidad y lealtad -contenidos en el mencionado Código-, documento que surge ante la necesidad de contar con una normativa que uniformice los principios rectores de la ética publicitaria. Cabe señalar que la vulneración de los derechos a la dignidad y a no ser discriminado en razón de sexo, debe perseguirse por medio de la aplicabilidad de los principio éticos incorporados en los artículos $8^{\circ}, 9^{\circ}, 10^{\circ}, 11^{\circ}, 12^{\circ}, 13^{\circ}$ y $14^{\circ}$ del Código de Ética Publicitaria del Perú que tenía su contraparte positivada (es decir, jurídica) en el artículo $3^{\circ}$ del Decreto Legislativo No. 691, (hoy artículo 18 del Decreto Legislativo 1044) el cual es exigible y coercitivo. Vemos entonces que en virtud del principio de legalidad, dichas reglas éticas son esencialmente coercitivas.

4 La Cedaw es un Tratado de Derechos Humanos, que fue aprobado por la Asamblea General de las Naciones Unidas 
En la doctrina podemos encontrar varios autores que también la definen; entre ellos, podemos citar a Manuel Santaella (1982) quien afirma que "(...) publicidad es cualquier información elaborada por un sujeto técnico publicitario, en interés de cualquier sujeto de derecho -anunciante-, con arreglo a una técnica especial y que se comunica o transmite a través de los medios de información, en los espacios o tiempos reservados a la publicidad, o en los medios de naturaleza exclusivamente publicitaria, con una finalidad informativo persuasiva o simplemente informativa." ${ }^{5}$

Por su parte, María Ángeles González Lobo, señala que "La publicidad consiste en divulgar, es decir, en publicar, poner algo al alcance del público. Lo que queremos poner al alcance del público son noticias o anuncios, pero no de cualquier tipo, sino de carácter comercial. $Y$ además lo hacemos con el objetivo de atraer compradores de nuestro producto, espectadores de nuestro acontecimiento o usuarios de nuestro servicio". ${ }^{6}$

Para Enrique Ortega, la publicidad es un "proceso de comunicación de carácter impersonal y controlado que, a través de medios masivos pretende dar a conocer un producto, servicio, idea o institución con objeto de informar o de influir en su compra o aceptación". ${ }^{7}$

Si bien, la definición sobre publicidad propuesta por los autores hacen mención a los sujetos intervinientes y finalidad de la misma, no cabe duda que, por los medios a utilizarse, esta resulta ser una comunicación dirigida a las masas, que mediante el uso de los diversos medios de comunicación como la radio, prensa y televisión, divulgan información escogida y relevante, previo pago o contraprestación económica al medio de comunicación y a las personas que intervinieron en la elaboración de dicha publicidad. Asimismo, es importante señalar que actualmente, según lo afirman Fernández Novoa y Carmen Aspíllaga ${ }^{8}$, la finalidad de la publicidad no solo sería de indole informativa (envío de un mensaje objetivo de tipo cognoscitivo) sino también de inducción, de persuasión al consumidor para la adquisición desusbienesy/oservicios, mediante el empleo de estímulos multimediáticos que buscan persuasivamente influir en la conducta de los receptores promoviendo una acción de compra por parte de ellos. Convirtiéndose así la publicidad comercial en un fenómeno realmente poderoso que influye sobre la conducta de los consumidores.

En algunas ocasiones, la publicidad a través de los estímulos que muestra puede no impactar de manera significativa en la conducta de los consumidores; sin embargo, en otras ocasiones sí puede influir de forma positiva o negativa. Es más, hay ocasiones en que los receptores reciben los mensajes publicitarios de manera distinta a lo que realmente querían los emisores de la publicidad, por lo que la excusa "no quise decir eso con mi anuncio difundido" no es necesariamente válido en todos los casos para oponer falta de responsabilidad legal.

Cuando estamos ante la presencia de publicidad con contenidos que encierran el respeto a los valores, los consumidores confirman dichos valores arraigados previamente en ellos. Sin embargo, también podemos estar ante la presencia de publicidad que contiene antivalores que al ser almacenado por los consumidores en su

mediante Resolución 34/180 del 18 de diciembre de 1979 y suscrita por el Estado peruano el 23 de julio de 1981 . El 1 de junio de 1982 el Congreso de la República del Perú aprobó la Convención sobre la eliminación de todas las formas de discriminación contra la mujer, CEDAW (Committee on the Elimination of Discrimination against Women). Días después, el 5 de junio, el Presidente de la República hizo lo propio mediante la Resolución Legislativa N $^{\circ} 23432$.

Santaella López, Manuel. (1982) Introducción al derecho de la publicidad. Madrid: Civitas, p. 170.

Gonzalez Lobo, María Ángeles (1994). Curso de publicidad. Madrid: Editorial Eresma y Celeste.

Ortega Enrique (1977) La comunicación publicitaria. Madrid: Editorial Pirámide.

8 Fernandez Novoa, Carlos. Estudios de derecho de la publicidad. p. 512. En Universidad de Lima. Derecho. Separata de la Maestría de Derecho de la Empresa. Tema: La interpretación jurídica de las expresiones publicitarias. Aspíllaga Pazos, Carmela. Capacidad educativa de la publicidad. Piura, Publicaciones Universidad de Piura, $1^{\circ}$ edición, 1990, p. 85, ambos citados por Mock Ferreyros, Francisco Javier. En: Publicidad Discriminatoria en razón de género. Quiebre del principio de predictibilidad de las resoluciones administrativas para incorporar nuevo criterio jurisprudencial en defensa de los derechos humanos. www.glsabogados.com . Consultado en junio de 2013. 
memoria, en forma inconsciente, puede que con el paso del tiempo, influir en asumir determinadas actitudes no del todo positivas frente a la vida y a los demás. En tal sentido, por ejemplo, el valor de dignidad de la persona humana, específicamente el de la mujer, es uno que ha sido vulnerado en muchas ocasiones mediante la difusión de publicidad denominada publicidad "sexista".

Según la Real Academia de la Lengua Española, entendemos por:

Sexismo: 1. m. Atención preponderante al sexo en cualquier aspecto de la vida. 2. m. Discriminación de personas de un sexo por considerarlo inferior al otro.

Asimismo, el sexismo tiene distintas formas de expresión, por ejemplo el androcentrismo: 1. m. - Visión del mundo y de las relaciones sociales centrada en el punto de vista masculino. O el machismo: 1. m. - Actitud de prepotencia de los varones respecto de las mujeres.

No cabe duda que los publicistas a menudo recurren al sexo y al erotismo para vender. En los anuncios se utilizan escenas e imágenes con un contenido erótico y sexual como elemento de atracción. El uso de la mujer como objeto/ornamentación agradable a la vista y como fuerza para atraer la atención de potenciales clientes masculinos es una constante en la publicidad para vender desde coches hasta caramelos. Según Elósegui (1998), es un nuevo tipo de subordinación de la mujer con respecto al varón, que supone un retroceso al modelo de los años sesenta, con nuevas connotaciones. De hecho, en el discursos publicitario, "la presencia femenina sirve como reclamo para vender todo tipo de productos, viéndose reducida en gran cantidad de ocasiones a un mero objeto sexual" (Del Moral, 2000, p. 216) $)^{9}$.

No hemos encontrado una definición legal sobre publicidad sexista, ni tampoco normatividad que defina cuándo estamos ante una publicidad que ofende propiamente a la dignidad de la mujer; sin embargo, nos parece interesante el trabajo elaborado por un grupo de especialistas en diversas materias convocados por el Consejo Sueco Nacional de Políticas del Consumidor (CSNPC $)^{10}$ con el fin de elaborar una propuesta para la definición de publicidad sexista. El resultado del trabajo fue la proposición de los siguientes criterios base para catalogar si una publicidad es sexista o no:

1. La que se usa a la mujer como objeto para llamar la atención.

2. En la que no hay ninguna razón, ni relevancia para la presencia de la mujer en relación a un producto determinado.

3. En la que la mujer es retratada de forma poco digna en relación al contexto, por ejemplo con su cuerpo en una pose antinatural.

4. La que utiliza insinuaciones sexuales y hace promesas que son irrelevantes para el producto.

a. Publicidad en que la mujer/ hombre es explotada/do como un objeto.

b. Publicidad que retrata a la mujer como una criatura pasiva, una persona carente de valor intrínseco que obtiene su autoestima a través de otros.

c. Publicidad que expresa que el rol de la mujer es satisfacer a otros.

5. La que da una visión falsa de la contribución de las mujeres o de los hombres a la vida del trabajo.

6. La que refuerza el estereotipo de los sexos en la sociedad.

7. La que declara que el rol de la mujer es agradar al hombre.

8. La que representa a hombres activos en roles profesionales, mientras que se muestra a las mujeres semidesnudas en el baño.

9. La que representa una visión estereotipada de los rasgos de la personalidad de las mujeres y de los hombres.

\footnotetext{
9 Del Moral Perez, E. (2000) "Los nuevos modelos de mujer y de hombre a través de la publicidad" En Comunicar № 14 págs 208-217.

10 Citado por Julio Duran. Ver Debates Jurídicos - 12/10/08: Publicidad Sexista: Cuidado. En : http://www.derecho.usmp.edu. pe/centro_derecho_competencia/frame_actividades_debate04.html. Consultado en junio de 2013.
} 
10. La que retrata nuestras habilidades y ambiciones en el trabajo y en el hogar de manera tal que solo puede ser contraproducente para los esfuerzos de lograr la igualdad entre el hombre y la mujer.

11. La dirigida a los niños que les da impresiones falsas y pasadas de moda de lo que es característico de los hombres y de las mujeres.

12. La que relaciona la velocidad y la fuerza con el mundo del niño mientras que las emociones, la suavidad y la ternura se asocian al mundo de la niña.

13. La que muestra niños activos y concentrados en sus juegos mientras que las niñas están solo concentradas en sí mismas.

Como señala Royo Vela (2002), los roles femeninos que se muestran en la publicidad, aunque se han ido modernizando paulatinamente y adaptando al papel real desempeñado por la mujer en nuestra sociedad, todavía presentan estereotipos sexistas. ${ }^{11}$

Resulta, pues increíble que estos criterios elaborados representan toda aquella publicidad divulgada en los medios de comunicación donde la mujer era considerada propiamente como objeto/ornamento en la publicidad y que lastimosamente su contenido no contribuía a concientizar en la sociedad aquella igualdad de género entre hombre y mujer que tanto se luchó en reconocer en el campo jurídico.

Coincidimos con Peña y Fabretti quienes señalan que "La publicidad juega un papel decisivo como instrumento de comunicación social, siendo capaz (...) de conformar modelos colectivos de valores y comportamientos, ofreciendo al público no solo productos, sino también modelos de actitudes, formas de vida e imágenes paradigmáticas que orientan y en muchos casos definen las necesidades y los deseos de las personas. Es cierto que resulta difícil concebir la publicidad sin el uso de estereotipos, pero en una cultura donde la igualdad entre géneros se presenta como un valor, no podemos preservar imágenes basadas en tópicos negativos sobre mujeres y hombres que sirvan como elemento de perpetuación de una cultura patriarcal de dominación de los hombres sobre las mujeres". ${ }^{12}$

\section{ANÁLISIS DE LAS RESOLUCIONES DE INDECOPI}

Para la redacción del presente artículo se tomaron como referencia 03 resoluciones expedidas por la Comisión de Defensa de la Competencia del INDECOPI (en adelante la Comisión), durante los años 2006 al 2008, y colgadas en la página web de dicha entidad. Dos de las respectivas denuncias que dieron origen a los procedimientos administrativos, fueron interpuestas por la ONG DEMUS, mientras que en solo uno de los casos, el procedimiento administrativo fue iniciado de oficio por la propia Comisión. El sustento legal de las denuncias se fundamentaba en una presunta infracción al Principio de Legalidad señalando que las empresas anunciantes habrían violado normas de la Constitución y normas publicitarias, como el artículo $3^{\circ} \mathrm{de}$ la Ley de Publicidad en Defensa del Consumidor (Decreto Legislativo 691) vigente en ese entonces, afectando mediante su publicidad la dignidad de las mujeres y estimulando así la discriminación contra el género femenino.

Las resoluciones que se analizan en relación al tema, son las siguientes:

11 Royo Vela, M; Miquel Roero, M.J; Caplliure Giner, E. M. (2002) "La publicidad como reflejo de la realidad social: un análisis descriptivo de los roles de género y sexismo en la publicidad en revistas en el último año del siglo XX". En Arxius $\mathrm{N}^{\circ}$ 6, p. 165-191.

12 Peña-Marin, Cristina; Fabretti, Carlos (1990) La mujer en la publicidad. Madrid. Ministerio de Asuntos Sociales, Instituto de la Mujer; p. 46. 


\begin{tabular}{|c|c|c|}
\hline RESOLUCIÓN & PARTES & SUMILLA \\
\hline $\begin{array}{l}\text { No 163-2006/CCD- } \\
\text { INDECOPI } \\
\text { CASO: } \\
\text { DIRECTV }\end{array}$ & $\begin{array}{l}\text { DENUNCIANTE: } \\
\text { COMISIÓN DE REPRESIÓN } \\
\text { DE LA COMPETENCIA } \\
\text { DESLEAL } \\
\text { (LA COMISIÓN) } \\
\text { DENUNCIADA: } \\
\text { DIRECTV PERÚ S.R.L. } \\
\text { (DIRECTV) }\end{array}$ & $\begin{array}{l}\text { Se declara FUNDADA la imputación de oficio } \\
\text { contra Directv por infracción al principio de } \\
\text { legalidad, establecido en el artículo } 3 \text { del Decreto } \\
\text { Legislativo } N^{\circ} 691 \text { - Normas de la Publicidad } \\
\text { en Defensa del Consumidor. En consecuencia, } \\
\text { se SANCIONA a Directv con una amonestación } \\
\text { y se ORDENA su inscripción en el registro } \\
\text { de infractores. } \\
\text { Asimismo, se ORDENA a Directv, como } \\
\text { medida complementaria, el cese DEFINITIVO e } \\
\text { INMEDIATO de la difusión del anuncio declarado } \\
\text { infractor. }\end{array}$ \\
\hline $\begin{array}{l}\text { № 205-2007/CCD- } \\
\text { INDECOPI } \\
\text { CASO: } \\
\text { DESODORANTE } \\
\text { AXE }\end{array}$ & $\begin{array}{l}\text { DENUNCIANTE: DEMUS } \\
\text { ESTUDIO PARA LA DEFEN- } \\
\text { SA DE LOS DERECHOS DE } \\
\text { LA MUJER } \\
\text { (DEMUS) } \\
\text { DENUNCIADA: } \\
\text { UNILEVER ANDINA PERÚ } \\
\text { S.A. } \\
\text { (UNILEVER) }\end{array}$ & $\begin{array}{l}\text { Se declara INFUNDADA la denuncia presentada } \\
\text { por Demus contra Unilever por infracción contra } \\
\text { el principio de legalidad, establecido en el artículo } \\
3 \text { del Decreto Legislativo } N^{\circ} 691 \text { - Normas de la } \\
\text { Publicidad en Defensa del Consumidor. } \\
\text { En consecuencia, se DENIEGA el pedido para } \\
\text { que Unilever asuma el pago de las costas y los } \\
\text { costos incurridos por Demus en el tramite del } \\
\text { presente procedimiento. }\end{array}$ \\
\hline $\begin{array}{l}\text { No 185-2008/CCD- } \\
\text { INDECOPI } \\
\text { CASO: } \\
\text { GLOBOPOP LOVE }\end{array}$ & $\begin{array}{l}\text { DENUNCIANTE: DEMUS } \\
\text { ESTUDIO PARA LA } \\
\text { DEFENSA DE LOS } \\
\text { DERECHOS DE LA MUJER } \\
\text { (DEMUS) DENUNCIADA: } \\
\text { CONFIPERÚ S.A. } \\
\text { (CONFIPERÚ) }\end{array}$ & $\begin{array}{l}\text { Se declara INFUNDADA la denuncia presentada } \\
\text { por Demus contra Confiperú por la presunta } \\
\text { infracción al principio de legalidad, establecido } \\
\text { en el artículo } 3 \text { del Decreto Legislativo } N^{\circ} \\
691 \text { - Normas de la Publicidad en Defensa del } \\
\text { Consumidor. En consecuencia, se DENIEGA el } \\
\text { pedido de pago de costas y costos formulado } \\
\text { por Demus. }\end{array}$ \\
\hline
\end{tabular}

Como podemos apreciar del cuadro anterior, de las 3 resoluciones dos de ellas fueron declaradas infundadas, lo que nos lleva a formular la siguiente pregunta: ¿Se ha aplicado correctamente el cumplimiento al Principio de Legalidad? ¿Se ha protegido a la mujer de la supuesta violación a su dignidad por medio de la una publicidad sexista? ¿Cuáles han sido los criterios que la autoridad administrativa ha valorado para no considerarlo como publicidad sexista?

\section{CRITERIOS Y NORMAS APLICABLES EN LAS RESOLUCIONES}

La normativa vigente en el campo de la publicidad, aplicable a los casos que analizamos, era el Decreto Legislativo 691. Asimismo, en las tres resoluciones analizadas hemos encontrado que la Comisión reconocía a los anunciantes libertad para difundir sus mensajes publicitarios. El fundamento a esa libertad está previsto en el artículo 58 de la Constitución Política del Perú de $1993^{13}$, norma que establece como regla general que la iniciativa privada en materia económica es libre y que la misma se ejerce en una economía social de mercado; así como en el artículo 59 del mismo cuerpo constitucional ${ }^{14}$, cuyo tenor indica que el Estado garantiza la liberad de empresa, comercio e industria. Sin embargo, es necesario resaltar que dicha libertad no es absoluta sino que está sujeta a restricciones. Por ejemplo, el propio artículo

\footnotetext{
13 Constitución Política del Perú - 1993: Artículo 58.- Economía Social de Mercado.

La iniciativa privada es libre. Se ejerce en una economía social de mercado. Bajo este régimen, el Estado orienta el desarrollo del país, y actúa principalmente en las áreas de promoción de empleo, salud, educación, seguridad, servicios públicos e infraestructura.

14 Constitución Política del Perú -1993 : Artículo 59.- Rol Económico del Estado.
} 
59 de la Constitución Política del Perú agrega que, si bien el Estado garantiza la libertad de empresa el ejercicio de las mismas no debe ser lesivo a la moral, a la salud, ni a la seguridad pública. De igual modo, la Constitución Política recoge los derechos fundamentales de las personas, señalando en el artículo $1^{\circ}$ que su defensa y el respeto de su dignidad (el subrayado es nuestro) son el fin supremo de la sociedad y del Estado. ${ }^{15}$

Asimismo, la Comisión fundamentó sus resoluciones basándose en el artículo $2^{\circ}$ del Decreto Legislativo 691 -Normas de la Publicidad en Defensa del Consumidor- el mismo que señalaba lo siguiente:

Artículo 2.- Las normas deben interpretarse y aplicarse de buena fe, en armonía con los principios de la ética o deontología publicitaria generalmente aceptados.

Los anuncios deben ser juzgados teniendo en cuenta el hecho que el consumidor queda influenciado mediante un examen superficial del mensaje publicitario.

Las normas se aplican a todo el contenido de un anuncio, incluyendo las palabras y los números, hablados y escritos, las presentaciones visuales, musicales $y$ efectos sonoros.

Al respecto, cabe mencionar que la Comisión ha señalado en diversos pronunciamientos que dicho examen "superficial" debe entenderse que el consumidor no hace un análisis exhaustivo y profundo del anuncio, y por lo tanto, las expresiones publicitarias no deben ser interpretadas fuera del contexto en que se difunden, debiéndose tener en cuenta todo el contenido del anuncio, como las palabras y los números, hablados y escritos, las presentaciones visuales, musicales y los efectos sonoros, porque el consumidor aprehende integralmente el mensaje publicitario. Otro fundamento que la Comisión consideró en las resoluciones fue el artículo $3^{\circ}$ del mismo cuerpo normativo, el mismo que señalaba lo siguiente:

Artículo 3.- Los anuncios deben respetar la Constitución y las leyes.

Ningún anuncio debe favorecer o estimular cualquier clase de ofensa o discriminación racial, sexual, social, política o religiosa. Los anuncios no deben contener nada que pueda inducir a actividades antisociales, criminales $o$ ilegales o que parezca apoyar, enaltecer o estimular tales actividades. (el resaltado es nuestro)

Hasta aquí, hemos mencionado la normatividad y criterios aplicados por la Comisión en las tres resoluciones bajo análisis. A continuación, veremos que según el caso planteado, la interpretación normativa y los criterios, varían.

\section{APLICACIÓN A LOS CASOS}

\section{CASO "DIRECTV"}

\section{Resolución N 163-2006/CCD-INDECOPI}

ANUNCIO PUBLICITARIO: Se presenta la imagen en un anuncio publicitario (panel) de una parte de un cuerpo femenino, evocando una situación erótica, con la finalidad de promocionar un canal de televisión dirigido al público masculino.

La Comisión inició el presente procedimiento de oficio. Dicho órgano del INDECOPI debía verificar si el mensaje publicitario infringía o no el Principio de Legalidad por favorecer o estimular una ofensa o una discriminación sexual, previsto en el artículo 3 del Decreto Legislativo 691.

El Estado estimula la creación de riqueza y garantiza la libertad de trabajo y la libertad de empresa, comercio e industria. El ejercicio de estas libertades no debe ser lesivo a la moral, ni a la salud, ni a la seguridad públicas. El Estado brinda oportunidades de superación a los sectores que sufren cualquier desigualdad; en tal sentido, promueve las pequeñas empresas en todas sus modalidades.

15 Constitución Política del Perú -1993 Artículo 1.- Defensa de la persona humana.

La defensa de la persona humana y el respeto de su dignidad son el fin supremo de la sociedad y del Estado. 
Artículo 3.- Los anuncios deben respetar la Constitución y las leyes.

Ningún anuncio debe favorecer $O$ estimular cualquier clase de ofensa $O$ discriminación racial, sexual, social, política o religiosa. Los anuncios no deben contener nada que pueda inducir a actividades antisociales, criminales $o$ ilegales o que parezca apoyar, enaltecer o estimular tales actividades. (el resaltado es nuestro)

La Comisión, expuso en la parte considerativa de su resolución que este artículo señalaba dos supuestos diferenciados: a) el acto de

favorecer o estimular una ofensa o una conducta discriminante, que no es igual ni tiene el mismo alcance que b) el acto de inducir, apoyar, enaltecer o estimular actividades antisociales, criminales o ilegales. En el primer caso, la prohibición sobre dichos actos-según la Comisión-reside en la necesidad de proteger directamente a las personas como sujetos de derecho, al exigirse que no se favorezca o estimule cualquier atentado contra su dignidad a través de conductas ofensivas o discriminantes. En el segundo caso, la prohibición sobre dichos actos reside en la necesidad de cautelar el orden público. "Así, el bien jurídico protegido al momento de sancionar la publicidad capaz de favorecer o estimular cualquier conducta ofensiva o discriminante, es la dignidad de las personas y su condición de igualdad protegida a través de derechos constitucionales (el subrayado es nuestro) ; mientras que el bien jurídico tutelado al momento de sancionar la publicidad capaz de inducir a actividades antisociales, criminales o ilegales o que parezca apoyar, enaltecer o estimular tales actividades es que no se promueva la vulneración de la moral, la salud y la seguridad pública a los cuales se refiere el artículo 59 de la Constitución."16, interpretación que coincidimos toda vez que la actividad publicitaria por más libertad que pueda gozar al momento de difundirse, deberá considerar la existencia de un interés de la sociedad protegido por el ordenamiento jurídico constitucional y que es superior a los intereses privados de los anunciantes, como es el respeto a la dignidad de las personas, la protección del interés superior del niño, las poblaciones vulnerables, el anciano, la mujer. ${ }^{17}$

No obstante la aplicación e interpretación del artículo 3 del Decreto Legislativo 691 al presente caso, la Comisión procedió a formular, adicionalmente, las siguientes preguntas a fin de determinar si el anuncio infringía o no las normas de publicidad vigentes (Principio de Legalidad) por favorecer o estimular una ofensa o una discriminación racial, sexual, política o religiosa. Las respuestas a las preguntas formuladas fueron las siguientes:

i. En qué consiste la acción de favorecer o estimular? En una distinción o diferenciación sobre la presentación del cuerpo femenino respecto del masculino, pues el primero es presentado como símbolo u objeto de atracción para los hombres;

ii. ¿Cuáles son las conductas mostradas en la publicidad en particular? La imagen de una parte del cuerpo femenino (concretamente caderas $y$ nalgas de una mujer) de una manera desproporcionada, excesiva $y$, en consecuencia, injustificada, al mostrarse a la mujer en la acción de desnudarse completamente;

iii. ¿De qué manera tales conductas pueden favorecer y/o estimular una ofensa o una manifestación discriminante? Un

16 Ver Resolución N N 163-2006/CCD-INDECOPI; Resolución Nº 205-2007/CCD-INDECOPI y Resolución Nº 185-2008/ CCD-INDECOPI.

17 Recordemos que el Perú suscribió la Convención para la eliminación de todas las formas de discriminación contra las mujeres (CEDAW), adoptada en 1.979 por la Asamblea General de las Naciones Unidas, documento donde define el término discriminación contra las mujeres como “... cualquier distinción, exclusión a restricción basada en el sexo que tenga por objeto o por resultado menoscabar o anular el reconocimiento, goce o ejercicio por la mujer, independientemente de su estado civil, sobre la base de la igualdad del hombre y la mujer, de los derechos humanos y las libertades fundamentales en las esferas política, económica, social, cultural y civil o en cualquier otra esfera." En tal sentido, los Estados partes, incluido el Perú, han acordado adoptar todas las medidas apropiadas, incluyendo cambios en la legislación y medidas especiales provisionales, de forma que las mujeres puedan disfrutar de todos sus derechos humanos y libertades fundamentales. 
efecto negativo sobre las mujeres en general, pues ello podría favorecer algún tipo de discriminación u ofensa sexual respecto de las mujeres, fomentando patrones estereotipados que las colocan en situaciones de subordinación frente a la satisfacción erótica de los hombres, al presentar la imagen de una parte del cuerpo de una mujer como un objeto para captar su atención, respecto de determinado tipo de productos dirigidos al público masculino.

Como resultado, la Comisión estimó que de la apreciación de la imagen y del mensaje del anuncio cuestionado mostraban una subordinación de una parte del cuerpo femenino o de su totalidad a la satisfacción erótica masculina, acompañado de la afirmación "te espero en casa". En tal sentido, para la Comisión, el mensaje del anuncio buscaba asociar el contenido del canal televisivo promocionado, no solamente con el erotismo de la imagen que muestra, sino además con la sujeción de la mujer frente a la satisfacción del hombre, a través de la misma, por lo que declararon fundada la denuncia interpuesta.

Asimismo, siguiendo el espíritu de la protección de la dignidad de las personas, la Comisión en su resolución, también interpretó el artículo 5 del Reglamento de la Ley de Normas de la Publicidad en Defensa del Consumidor (D.S. $\mathrm{N}^{\circ}$ 20-94-ITINCI), bajo el mismo espíritu de protección contenido en el artículo $3^{\circ}$ del Decreto Legislativo 691, señalando que la libertad en el uso del humor, de la fantasía y/o de la exageración en la publicidad comercial, deberá ser limitada con mayor incidencia cuando tales licencias se utilicen de modo tal que puedan favorecer o estimular cualquier atentado contra la dignidad de las personas a través de conductas ofensivas o discriminantes, que cuando las mismas sean capaces de promover la vulneración del orden público o de las buenas costumbres, dada la mayor ponderación del interés protegido en el primer caso, frente al segundo.
Por estas razones, la Comisión declaró FUNDADA la denuncia interpuesta por considerarla atentatoria al Principio de Legalidad y a la dignidad de la mujer. Sin embargo, en los siguientes casos, como veremos a continuación, la interpretación de las normas varía.

\section{CASO DESODORANTE "AXE" Resolución N N 205-2007/CCD-INDECOPI}

ANUNCIO PUBLICITARIO: El anuncio muestra a un hombre aplicándose desodorante AXE en la parte baja del cuerpo, luego una mujer entrando bajo una mesa, se arrodilla para besar y acariciar el pie de un hombre, de manera sugerente, generándole placer a este último. Dicha imagen apreciada de manera conjunta con la frase "márcales el camino".

A diferencia del caso anterior, la Comisión resolvió declarando INFUNDADA LA DENUNCIA, basándose principalmente en la aplicación del artículo $5^{\circ}$ del Reglamento de la Ley de Normas de Publicidad en Defensa del Consumidor (D.S. N ${ }^{\circ} 20-94$-ITINCI) ${ }^{18}$ :
Artículo $5^{\circ}$.- En la publicidad comercial está permitido el uso del humor, la fantasía y la exageración, en la medida en que tales recursos no impliquen un engaño para el consumidor o constituyan infracción a las normas sobre publicidad. Los anuncios en los que se realice exhibición de juguetes que involucren la construcción, modelaje, pintura, dibujos y similares, no deberán exagerar las facilidades de su ejecución.

Según el criterio de la Comisión para el presente caso, el uso del humor y/o fantasíano podría generar conductas que provoquen sometimiento o sujeción de la mujer afectando su dignidad.

Sin embargo, nos preguntamos: ¿Y la concordancia con el espíritu de protección a la dignidad de las personas y los derechos fundamentales de la misma previsto en el

18 Actualmente dicha disposición normativa ha sido derogada por el Decreto Legislativo 1044. 
artículo 3 del Decreto Legislativo 691? Queda claro que para este caso no se aplicó.

Adicionalmente, la Comisión, expuso en su resolución, que un consumidor entiende que está frente a un anuncio que opta por utilizar el humor y la fantasía para publicitar su producto porque muestra a un joven que, al utilizar el desodorante "Axe" consigue tener un imaginario $e$ irresistible atractivo. En ese sentido, para la Comisión, "ninguna fragancia podría generar, luego de ser rociada en el cuerpo, una reacción de atracción irresistible en el sexo opuesto tal como la mostrada en el anuncio denunciado y que entender lo contrario significaría aplicar sobre el anuncio cuestionado una interpretación alambicada y/o forzada". Añadió además que a causa de su evidente tono humorístico y de fantasía no sería capaz de estimular, en la realidad, trato alguno de inferioridad contra una mujer o alguna conducta que afecte su dignidad por consideraciones de subordinación erótica respecto de lo masculino, sujeción sexual o cosificación. El humor y la fantasía que utilizó el anuncio cuestionado fue -a criterio de la Comisión- un elemento que impedía tomar en serio las imágenes que se muestran o tomar al pie de la letra una afirmación tal como "márcales el camino correctamente", en el contexto integral y superficial del análisis de dicho anuncio.

Por tanto, la Comisión concluyó que el anuncio materia de denuncia no era capaz de favorecer o estimular algún tipo de discriminación u ofensa sexual respecto de las mujeres, en tanto que en el mismo predomina el humor y la fantasía, licencias permitidas por nuestro ordenamiento y que, en el presente caso, no pueden generar sobre el público femenino conductas dirigidas a provocar su sometimiento o sujeción de manera que se afecte la dignidad que le reconoce la Constitución y demás normas que conforman el ordenamiento jurídico.

Sin embargo, si analizamos el anuncio publicitario de la misma manera como se realizó en el caso "Directv", para establecer si infringe o no el Principio de Legalidad, que es el objetivo mismo por determinar, el resultado sería: i. ¿En qué consiste la acción de favorecer o estimular? En una distinción o diferenciación sobre la presentación del cuerpo femenino respecto del masculino, pues el primero es presentado como símbolo u objeto de atracción para los hombres;

ii. ¿Cuáles son las conductas mostradas en la publicidad en particular? La imagen de una mujer que debajo de la mesa llega a acariciar y besar los pies de un hombre en un restaurante, quien se había puesto el desodorante de esa marca en la parte baja del cuerpo.

iii. ¿De qué manera tales conductas pueden favorecer y/o estimular una ofensa o una manifestación discriminante?. Un efecto negativo sobre las mujeres en general, pues ello podría favorecer algún tipo de ofensa o discriminación de carácter sexual respecto de las mujeres, fomentando patrones estereotipados que las colocan en situaciones de subordinación frente a la satisfacción erótica de los hombres, al presentar la imagen de una mujer como un objeto para captar su atención, respecto de determinado tipo de productos dirigidos al público masculino.

Por tanto, queda en forma evidente que por las respuestas a las preguntas formuladas la publicidad era propiamente sexista; sin embargo, en el presente caso, la Comisión no consideró la aplicación de estas tres preguntas para verificar si se infringía el Principio de Legalidad previsto en al artículo $3^{\circ}$ del Decreto Legislativo 691, y cuyas respuestas nos hubieran mostrado un claro contenido sexista, sino que consideró que en el anuncio publicitario el anunciante fantasea de manera humorística sobre las cualidades que podría tener la fragancia del desodorante; es decir, se centró en la forma de presentación del producto (objeto materia de difusión en la publicidad) sin hacer un análisis del papel que desempeña la mujer en dicha publicidad la cual es, sin lugar a dudas, lo más atrayente para el consumidor y que el acto ocasionó un sentimiento de ofensa hacia la dignidad de la mujer lo que motivó la correspondiente interposición de la denuncia. 
Asimismo, tampoco realizó una interpretación del artículo $5^{\circ}$ del Reglamento de la Ley de Normas de Publicidad en Defensa del Consumidor, concordándolo con el artículo $3^{\circ}$ del Decreto Legislativo 691 con la finalidad de proteger a la persona de aquellos actos en que la publicidad pueda estimular o favorecer un acto ofensivo con a su dignidad, estableciéndose así un límite a la actividad publicitaria, tal como sí se realizó en el caso "Directv". Por el contrario, añadió que los actos infractores, contrarios al Principio de Legalidad, en general, debían generar conductas socialmente inaceptables y no ser solamente de mal gusto. Así, la Comisión citó jurisprudencia de la Sala de Defensa de la Competencia del Tribunal del INDECOPI que indicaba lo siguiente: "los anunciantes tienen el derecho de transmitir sus mensajes de la manera que mejor convenga a sus intereses, incluso si estos pudiesen ser considerados como de mal gusto, desagradables o impertinentes. Son el mercado, los consumidores y las organizaciones civiles, mas no una autoridad gubernamental, los que deben enviar mensajes a los anunciantes para que modifiquen sus anuncios, optando por no comprar o contratar los productos o servicios que se ofertan, promoviendo debates o difundiendo mensajes institucionales o educativos." (Ver Resolución No 205-2007/CCD-INDECOPI ).

\section{CASO “GLOBOPOP LOVE”}

Resolución N 185-2008/CCD-INDECOPI

ANUNCIO PUBLICITARIO: El anuncio se inicia presentando la imagen de una mujer caminando por la vía pública, sin que se le pueda apreciar el rostro. Asimismo, la protagonista del anuncio viste un polo verde claro con tiras que le llega hasta el ombligo y un pantalón denominado "jean de tiro bajo" de color azul, enfocándose el torso y parte de las piernas mientras camina. Simultáneamente, se aprecia que la referida mujer atrae la atención de todos los varones que están cerca de ella, quienes tienen diferentes percances, tales como golpearse con un poste, caerse de una silla y caerse en una pileta de agua. Luego se escucha que la locución en off señala: "iCuidado! El nuevo Globopop Love te puede seducir cuando menos te lo esperas." Posteriormente, la toma se abre y se observa la figura completa de la mujer, en medio de la calle mirando hacia el horizonte, degustando el producto denominado "Chupete Globopop Love", enfocándose la ropa interior de la mujer, la cual tiene un estampado con el término "love", mientras la locución en off señala: "Nuevo Globopop Love, un chupete con seductores tatuajes para la ropa, que hablarán por ti." A la vez se enfocan varias prendas tatuadas con los términos "love"; "hot"; "kiss"; y, "sexy". Enseguida, se muestra a la mujer consumiendo el producto anunciado y mirando a un varón que la observa de la misma forma y realizando la misma acción. La mujer en cuestión vuelve a consumir el chupete anunciado y al sacarlo ambos se acercan y se besan. El anuncio televisivo concluye con la locución en off señalando: "iNuevo Globopop Love, te seduce con la ropa!".

Para la denunciante (DEMUS), en el anuncio publicitario del producto "Chupete Globopop Love", la mujer sería presentada de manera subordinada, en la medida que se mostraría parte de su cuerpo como un objeto de satisfacción erótica para el varón, atentando contra la imagen de la mujer y su dignidad, (ver lo subrayado en el párrafo anterior), contraviniendo de esta manera el Principio de Legalidad previsto en el ordenamiento jurídico añadiendo además que si bien las personas, independientemente de su edad, pueden consumir chupetes de caramelo, dicho producto tendría como consumidores principales a niños y adolescentes. En tal sentido, la denunciante añadió que el anuncio cuestionado captaría la atención de los niños, quienes podrían verse influenciados por la representación "sexualizada" y desvalorizada de la mujer presentada en el mismo.

Por su parte, la denunciada Confiperú en sus descargos, señaló que las imágenes del anuncio cuestionado mostrarían una forma vestir que estaría de moda; que el pantalón utilizado por la protagonista del anuncio sería un "jean de tiro bajo", el mismo que permite mostrar la ropa interior, la misma que, en la actualidad, ostentaría las funciones estéticas de una prenda exterior. Adicionalmente, dicha empresa manifestó también que la publicidad de su producto "Chupete Globopop Love", no 
estaría dirigida a los niños, sino a un público joven adulto, tal como se podría apreciar de los personajes que aparecen en el anuncio cuestionado.

En este caso en particular, la Comisión declaró INFUNDADA la denuncia porque consideró que la publicidad no transmitía un mensaje capaz de favorecer o estimular, en la realidad, conductas ofensivas o discriminatorias en contra de la mujer, ni mucho menos que afecte su dignidad como persona, por cuanto se limitaba a mostrar una tendencia actual en su forma de vestir, sin incluir carga negativa alguna respecto de dicha tendencia. Asimismo, señaló que la representación de conductas que exageran la atracción que sienten los varones por la protagonista del anuncio cuestionado, tampoco configuraba un mensaje que pudiera generar, en la realidad, conductas ofensivas o discriminatorias en contra de la mujer, debido a que se muestran deliberadamente exageradas y en tono humorístico, además de que la atracción que pueda sentir un ser humano respecto de otro del sexo opuesto, por sí misma, es un hecho natural y no ofensivo o discriminatorio.

Según criterio de la Comisión la publicidad denunciada no era capaz de apoyar o incitar conducta alguna distinta a la de consumo del producto anunciado, a causa de su evidente tono humorístico y de fantasía (aplicación del artículo $5^{\circ}$ del Reglamento de la Ley de Normas de Publicidad en Defensa del Consumidor (D.S. N $N^{\circ}$ 20-94-ITINCI); menos aún -señaló- sería capaz de estimular, en la realidad, trato alguno de inferioridad contra una mujer o alguna conducta que afecte su dignidad por consideraciones de subordinación erótica respecto de lo masculino, sujeción sexual o cosificación. En consecuencia, la Comisión consideró que no era posible sostener que el anuncio cuestionado favorece o estimula conductas que puedan significar, en la realidad, una manifestación discriminante $\mathrm{u}$ ofensiva en perjuicio de las mujeres; razón por la cual desestimó la denuncia interpuesta.

De igual modo que en el caso "Axe", para resolver el presente caso, la Comisión se apartó de una interpretación pro defensa de los dere- chos fundamentales de la persona del artículo $3^{\circ}$ del Decreto Legislativo 691 y tampoco lo concordó con el artículo $5^{\circ}$ del Reglamento de la Ley de Normas de Publicidad en Defensa del Consumidor, tal como había sido aplicado para resolver el caso "Directv" (Resolución No 163-2006/CCD-INDECOPI) Más aún, la Comisión expuso en la resolución, que "los anunciantes tienen el derecho de transmitir sus mensajes de la manera que mejor convenga a sus intereses, incluso si estos pudiesen ser considerados como de mal gusto, desagradables o impertinentes. Son el mercado, los consumidores y las organizaciones civiles, mas no una autoridad gubernamental, los que deben enviar mensajes a los anunciantes para que modifiquen sus anuncios, optando por no comprar o contratar los productos o servicios que se ofertan, promoviendo debates o difundiendo mensajes institucionales o educativos." Adicionalmente, señaló en su parte considerativa de su resolución que la Sala de Defensa de la Competencia del Tribunal del INDECOPI ha considerado además que "sostener que es rol del Estado determinar cuáles mensajes publicitarios son aceptables o adecuados, sancionando aquellos anuncios que difundan mensajes distintos, equivaldría a imponer el gusto o las opiniones de un grupo sobre el gusto o las opiniones de otros grupos de individuos que perfectamente pudiesen ser divergentes, lo cual incluso podría limitar la libertad de expresión."

\section{COMENTARIOS A LAS RESOLUCIONES}

En los tres casos antes expuestos, la autoridad administrativa tuvo presente el artículo $3^{\circ}$ del Decreto Legislativo 691 (vigente en ese entonces), norma que indicaba que la actividad publicitaria debía respetar la Constitución y las leyes; toda vez que la autoridad administrativa debía de decidir si había o no una infracción al Principio de Legalidad.

Artículo 3.- Los anuncios deben respetar la Constitución y las leyes.

Ningún anuncio debe favorecer o estimular cualquier clase de ofensa o discriminación racial, sexual, social, política o religiosa. Los anuncios no 
deben contener nada que pueda inducir a actividades antisociales, criminales $o$ ilegales o que parezca apoyar, enaltecer o estimular tales actividades.

De la redacción del artículo, podemos señalar que ningún contenido de algún anuncio, ni su difusión podían afectar los derechos fundamentales de las personas, ni los principios rectores del Estado ni del ordenamiento jurídico vigente; razón por la cual, resultaba evidente que la libertad de expresión de los anunciantes tenía como límite lo que nuestra Constitución Política y las leyes establecían. En tal sentido, como los casos expuestos versan sobre supuesta publicidad "sexista" contra la mujer, los derechos que podrían estar siendo vulnerados son el derecho de dignidad de la persona humana ${ }^{19}$ y a la no discriminación ${ }^{20}$, previstos en los artículos 1 y 2 de la Constitución Política del Perú de 199321.

Adicionalmente, el artículo $3^{\circ}$ del Decreto Legislativo 691 establecía como prohibición aquellos anuncios que tenían como impacto el "favorecer" o "estimular" cualquier clase de ofensa o discriminación racial, sexual, social, política o religiosa; prohibición que a su vez está presente en la propia Constitución y que también consideramos fue incluida en el Decreto Legislativo 691 como un énfasis en la protección de la dignidad y la no discriminación de la persona, toda vez que en materia de publicidad se utiliza la imagen de las personas pudiendo existir en el ejercicio de dicha actividad publicitaria un alto riesgo de caer en situaciones de vulneración de sus derechos fundamentales.

Sin embargo, cabe señalar que en el año 1997 , el Tribunal del INDECOPI, haciendo referencia al artículo $3^{\circ}$ del Decreto Legislativo 691, ya había sentado como precedente que "de una simple lectura de dicha norma se desprende que aquella no prohíbe la difusión de cualquier frase o imagen que pudiera ser considerada discriminatoria $u$ ofensiva, sino; en concreto aquellos que tengan como efecto o resultado "favorecer" o estimular" determinados tipos de discriminaciones $y$ ofensas: raciales, sexuales, sociales políticas o religiosas. Así "favorecer o estimular" implica que el anuncio objetivamente puede generar en el mundo real conductas ofensivas o discriminatorias de la naturaleza antes señaladas". (Res $\mathrm{N}^{\circ} 103$ 97-TDC en el expediente $\mathrm{N}^{\circ}$ 160-96-CCDINDECOPI, el subrayado es nuestro). ${ }^{22}$

En tal sentido, para el INDECOPI los anunciantes podían difundir publicidad discriminatoria y ofensiva a la dignidad de una persona siempre y cuando ello no genere ni ocasionen como resultado, la repetición de conductas ofensivas o discriminatorias en el mundo real, cuestión que además deberá ser materia de probanza por quien interponga la denuncia y verificado por la autoridad administrativa.

19 En efecto, la dignidad de cada persona humana constituye la base del Estado de Derecho y no en vano está prevista como primer artículo de la Constitución. La dignidad deriva del respeto debido a uno mismo y a los demás como seres humanos siendo los derechos humanos la expresión jurídica de todo un proceso mediante el cual se ha de proteger, respetar y garantizar a la persona el desarrollo de una vida digna. Asimismo, como cristianos, nuestro compromiso con la dignidad humana se deriva del reconocimiento de la persona humana creada como imagen de Dios y redimida por Cristo El reconocimiento de la dignidad de la persona humana es la base sobre la que descansan todos los derechos humanos.

20 La discriminación hacia la mujer está basada en formas de limitación en el ejercicio de sus derechos y libertades. Esta es la base de un conjunto de estereotipos y prácticas sexistas que desvalorizan lo femenino y a las mujeres como grupo poblacional. Dicha desvalorización está arraigada en creencias sobre el cuerpo y la sexualidad de las mujeres que se traducen en "deberes" que ellas deben cumplir "por naturaleza" en la familia y en la sociedad.

21 CONSTITUCIÓN POLÍTICA DEL PERÚ DE 1993

Artículo 1.- Defensa de la persona humana

La defensa de la persona humana y el respeto de su dignidad son el fin supremo de la sociedad y del Estado.

Artículo 2.- Derechos fundamentales de la persona

Toda persona tiene derecho:

1. A la vida, a su identidad, a su integridad moral, psíquica y física y a su libre desarrollo y bienestar. El concebido es sujeto de derecho en todo cuanto le favorece.

2. A la igualdad ante la ley. Nadie debe ser discriminado por motivo de origen, raza, sexo, idioma, religión, opinión, condición económica o de cualquiera otra índole."

22 En este sentido, la Sala en anteriores pronunciamientos ha precisado que "la ley no prohíbe la difusión de cualquier frase 
Sin embargo, en el caso "Directv", a diferencia de los otros dos casos, la resolución se apartó del criterio precedente del Tribunal del INDECOPI (Res $\mathrm{N}^{\circ}$ 103-97-TDC en el expediente $\mathrm{N}^{\circ}$ 160-96-CCD-INDECOPI), señalando que la lógica de la prohibición legal de los anuncios que favorezcan o estimulen cualquier tipo de ofensa o discriminación "reside en la necesidad de proteger directamente a las personas como sujetos de derechos" y que el bien jurídicamente protegido en este caso es "la dignidad de las personas y su condición de igualdad protegida a través de derechos constitucionales". Coincidimos con Mock Ferreyros ${ }^{23}$ al señalar que en la Resolución del caso "Directv", la autoridad administrativa al dejar sentado que lo que busca proteger con la referida disposición es la dignidad de la persona, da un paso positivo hacia el lado de la protección de los derechos fundamentales, pues este nuevo precedente es incompatible con la posición que sostiene que sólo está prohibido el anuncio que genera de manera objetiva, en el mundo real conductas discriminatorias y ofensivas.

En tal sentido, podemos señalar que hasta antes de la expedición de la Resolución del caso "Directv", en denuncias interpuestas en materia de publicidad sexista se debía probar el efecto desfavorable de la publicidad comercial, si ocurría de manera objetiva en el mundo real. Sin embargo, con la resolución del caso Directv, a partir del análisis del contenido del panel publicitario, la autoridad administrativa solo advirtió el peligro de generar ofensas y discriminaciones (obsérvese en el extracto tomado de la Resolución No 163-2006/CCDINDECOPI, líneas abajo, como se emplea el condicional "es capaz de" como equivalente a un "podría" en la respectiva parte considerativa de dicha Resolución, señalando además que la participación de la mujer en dicha publicidad no se encontraba acorde con el rol integral que le corresponde en la sociedad) $\mathrm{y}$, ante esa sola posibilidad, se consideró la infracción al artículo 3 del Decreto Legislativo 691 y la Constitución.

(...) En este caso, la Comisión aprecia que no se encuentra ante el simple uso de la belleza femenina, evocada por la presentación de una imagen del cuerpo de una mujer, lo cual no es per se ilegal sino que se encuentra ante un anuncio capaz de generar efectos que pueden favorecer discriminaciones $u$ ofensas de indole sexual, en perjuicio de la mujer.

Al respecto, se debe considerar que "favorecer" se entiende en el contexto del artículo 3 de las Normas de la Publicidad en Defensa del Consumidor como "apoyar un intento, empresa $u$ opinión"; "discriminar" se entiende como "dar trato de inferioridad a una persona o colectividad por motivos raciales, religiosos, políticos, etc"; y, "ofender" se interpreta como "humillar o herir el amor propio o la dignidad de alguien, o ponerlo en evidencia con palabras o con hechos".

En este sentido, a criterio de la Comisión, el anuncio cuestionado es capaz de desarrollar, incrementar o contribuir a perpetuar una consideración social indebida, y no deseada por el ordenamiento constitucional, que se refiere a estimar u opinar que la mujer, una parte de su cuerpo o la totalidad del mismo, se encuentran subordinados a la satisfacción erótica masculina.

Siendo, en este sentido, capaz de favorecer que en la sociedad se produzcan humillaciones respecto de la dignidad de la mujer o tratos de inferioridad o subordinación, por tal causa. Esta circunstancia, conforme al ordenamiento constitucional, no se encuentra acorde con el rol integral que corresponde a la

o imagen que pudiese ser considerada discriminatoria u ofensiva-de la misma manera que no prohíbe anuncios que presenten conductas antisociales, criminales o ilegales-, sino sólo de aquéllas que tengan como efecto o resultado "favorecer o estimular" determinados tipos de discriminaciones u ofensas: las raciales, sexuales, sociales, políticas o religiosas" (Ver Resolución 283-97/TDC-INDECOPI del 28 de noviembre de 1997; Resolución 0220-1998/TDC-INDECOPI del 19 de agosto de 1998; Resolución 0333-1999/TDC-INDECOPI del 29 de septiembre de 1999; Resolución 0360-1999/TDCINDECOPI del 20 de octubre de 1999; y, Resolución 2346-2007/TDC-INDECOPI del 26 de noviembre de 2007.

23 Mock Ferreyros, Francisco Javier. En: Publicidad Discriminatoria en razón de género. Quiebre del principio de predictibilidad de las resoluciones administrativas para incorporar nuevo criterio jurisprudencial en defensa de los derechos humanos. www.glsabogados.com . Consultado en junio de 2013. 
mujer en la sociedad. (el subrrayado es nuestro)

Por tanto, la Comisión concluye que el anuncio materia de imputación es capaz de favorecer algún tipo de discriminación u ofensa sexual respecto de las mujeres. En consecuencia, por las razones expuestas, la Comisión considera que el anuncio materia del presente procedimiento infringe el artículo 3 de las Normas de la Publicidad en Defensa del Consumidor." (Ver Resolución $N^{\circ}$ 163-2006/CCD-INDECOPI- el resaltado es nuestro)

Adicionalmente, en la resolución del caso "Directv", la Comisión interpretó el artículo $5^{\circ}$ del Reglamento de la Ley de Normas de la Publicidad en Defensa del Consumidor (D.S. $\mathrm{N}^{\circ}$ 20-94-ITINCI), en concordancia con el espíritu de protección contenido en el artículo $3^{\circ}$ del Decreto Legislativo 691, señalando que la libertad en el uso del humor, de la fantasía y/o de la exageración en la publicidad comercial, deberá ser limitada con mayor incidencia cuando tales licencias se utilicen de modo tal que puedan favorecer o estimular cualquier atentado contra la dignidad de las personas a través de conductas ofensivas o discriminantes, que cuando las mismas sean capaces de promover la vulneración del orden público o de las buenas costumbres, dada la mayor ponderación del interés protegido en el primer caso, frente al segundo. Interpretación con la cual coincidimos al ser fiel reflejo de la preocupación de proteger la imagen y dignidad de las personas.

Sin embargo, en los casos de Desodorante "Axe" y "Globopop Love", la autoridad administrativa en sus respectivas resoluciones declaró INFUNDADA las denuncias, apartándose así del criterio previsto en la Resolución del caso "Directv", utilizando principalmente el argumento del humor y fantasía (previsto en el artículo $5^{\circ}$ del Reglamento de la Ley de Normas de la Publicidad en Defensa del Consumidor) para extraer de esta forma a la publicidad comercial del ámbito de la protección de los derechos humanos. De tal modo, las denuncias que por "publicidad sexista" se interpusieron contra dichos asunciones publicitarios no se analizaron a la luz de la dignidad humana, pues fueron vistas como una cuestión de humor, y en tal sentido, como cuestiones de buen o mal gusto, dejándole al mercado, los consumidores, las organizaciones civiles, mas no la autoridad gubernamental, la potestad de poder censurarlo.

A continuación, recordemos los fundamentos $y$ argumentos que se consideraron en los casos Desodorante "Axe" y "Globopop Love":

Reglamento de la ley de normas de la Publicidad en Defensa del Consumidor (D.S. N ${ }^{\circ}$ 20-94-ITINCI),

Artículo $5^{\circ}$.- En la publicidad comercial está permitido el uso del humor, la fantasía y la exageración, en la medida en que tales recursos no impliquen un engaño para el consumidor o constituyan infracción a las normas sobre publicidad. (...)

Sala de Defensa de la Competencia del Tribunal del Indecopi

(...) sostener que es rol del Estado determinar cuáles mensajes publicitarios son aceptables o adecuados, sancionando aquellos anuncios que difundan mensajes distintos, equivaldría a imponer el gusto o las opiniones de un grupo sobre el gusto o las opiniones de otros grupos de individuos que perfectamente pudiesen ser divergentes, lo cual incluso podría limitar la libertad de expresión.

\section{Comisión:}

los anunciantes tienen el derecho de transmitir sus mensajes de la manera que mejor convenga a sus intereses, incluso si éstos pudiesen ser considerados como de mal gusto, desagradables o impertinentes. Son el mercado, los consumidores y las organizaciones civiles, mas no una autoridad gubernamental, los que deben enviar mensajes a los anunciantes para que modifiquen sus anuncios, optando por no comprar o 
contratar los productos o servicios que se ofertan, promoviendo debates $O$ difundiendo mensajes institucionales $o$ educativos.

¿Se puede camuflar aquella publicidad ofensiva /discriminante bajo el empleo del humor? Aparentemente, sí. El término humor, tal como lo define la Real Academia de la Lengua (RAE), significa lo siguiente: 1.m Genio, índole, condición, especialmente cuando se manifiesta exteriormente, 2.m Jovialidad, agudeza. Creemos que el término más apropiado que debió redactarse en el artículo $5^{\circ}$ del Reglamento de la Ley de Normas de la Publicidad en Defensa del Consumidor (D.S. No 20-94-ITINCI ) es el de "humorismo" dado que su significado según la RAE, es: $1 . m$ Modo de presentar, enjuiciar o comentar la realidad, resaltando el lado cómico, risueño o ridículo de las cosas. 2.m Actividad profesional que busca la diversión del público mediante chistes, imitaciones, parodias y otros medios.

Definitivamente el humorismo se utiliza en la publicidad con la finalidad que cualquier exageración pueda ser admitida pero siempre se debe tener el cuidado de no pretender ofender. El hacer sonreír a la gente mediante el humor, la exageración, resaltando el lado cómico, risueño o ridículo de las cosas, es un recurso muy utilizado para poder captar la atención del receptor y hacer al anuncio simpático y cercano y de fácil recordación. Sin embargo, ¿cuál sería el límite entre el humor y la ofensa o el acto discriminatorio? Pues el límite debería ser el respeto a los principios $y$ valores de la ética publicitaria los mismos que se encuentran inspirados en los Derechos Humanos.

Las imágenes difundidas en la publicidad de "Axe" donde se muestra a un hombre aplicándose el desodorante en la parte baja de su cuerpo, luego una mujer entra bajo una mesa, se arrodilla para besar y acariciar el pie del hombre de manera sugerente, generándole placer a este último apareciendo además la frase "márcales el camino", muestra a la mujer en una actitud de subordinación, sujeción hacia la figura del varón reforzando así el estereotipo del machismo que tanto daño hace en la sociedad. Adicionalmente, se refuerza mediante la frase "márcales el camino", difundiendo el mensaje que por la condición de ser mujer no son capaces de razonar ni de actuar por voluntad propia. La autoridad administrativa, en el presente caso, hizo solamente un análisis de la forma de presentación del objeto materia de la publicidad (el desodorante) mas no realizó un análisis sobre cómo es que la mujer está siendo representada con su imagen en la publicidad ante la sociedad. Para la Comisión, esta publicidad simplemente le resultaba también fantasiosa porque "ninguna fragancia podría generar, luego de ser rociada en el cuerpo, una reacción de atracción irresistible en el sexo opuesto tal como la mostrada en el anuncio denunciado y que entender lo contrario significaría aplicar sobre el anuncio cuestionado una interpretación alambicada y/o forzada". Añadió además que a causa de su evidente tono humorístico y de fantasía no sería capaz de estimular, en la realidad, trato alguno de inferioridad contra una mujer o alguna conducta que afecte su dignidad por consideraciones de subordinación erótica respecto de lo masculino, sujeción sexual o cosificación. El humorismo y la fantasía que utilizó el anuncio cuestionado fue, a criterio de la Comisión, un elemento que impedía tomar en serio las imágenes que se muestran o tomar al pie de la letra una afirmación tal como "márcales el camino correctamente", en el contexto integral y superficial del análisis de dicho anuncio. En nuestra opinión, sí representa un anuncio despectivo hacia la figura de la mujer, y que lamentablemente la autoridad administrativa solamente lo consideró fantasioso y humorístico.

Asimismo, en la publicidad del producto "Globopop Love", la autoridad administrativa no consideró que la imagen del cuerpo de la mujer nuevamente fue presentada de manera inapropiada en la publicidad. Recordemos que en dicha publicidad la protagonista del anuncio vestía un polo con tiras que le llegaba al ombligo y un pantalón "jean de tiro bajo", enfocándose el torso y parte de las piernas mientras camina. En otra escena, se le enfoca la ropa interior de la mujer la cual tiene un estampado el término "love". Consideramos que en esta publicidad 
se utilizó también la imagen del cuerpo de la mujer como el principal objeto de atracción para publicitar un chupete, dulce que también va dirigido a los niños. Sin embargo, la Comisión consideró que esta publicidad no transmitía un mensaje capaz de favorecer o estimular, en la realidad, conductas ofensivas o discriminatorias en contra de la mujer, ni mucho menos que afecte su dignidad como persona, por cuanto se limitaba a mostrar una tendencia actual en su forma de vestir, sin incluir carga negativa alguna respecto de dicha tendencia.

Emplear el argumento del humor y la fantasía de la manera como lo hizo la Comisión en los casos "Axe" y "Globopop Love", nos parece sumamente cuestionable porque cabría la posibilidad que de alguna manera se llegue a permitir la difusión de anuncios publicitarios con contenidos que lesionan la dignidad de la persona, sobre todo la de la mujer y que bajo el argumento de que es "divertido", "gracioso" o simplemente de "mal gusto", no pudieron ser sancionados en su oportunidad por la autoridad competente aún cuando podemos estar ante la presencia de publicidad cuya presentación humorística puede presentar situaciones indignas ${ }^{24}$.

Sin embargo, en el caso de "Directv" la resolución señalaba adicionalmente que "la libertad en el uso del humor, de la fantasía y/o de la exageración en la publicidad comercial deberá ser limitada con mayor incidencia cuando tales licencias se utilizan de modo tal que pueden favorecer o estimular cualquier atentado contra la dignidad de la persona a través de conductas ofensivas o discriminantes..." En este caso en particular, a diferencia de las otras dos resoluciones vemos que la autoridad administrativa asume el rol de protección de los derechos fundamentales de la persona, a través de una actuación positiva, en casos de "publicidad sexista"; mientras que en los casos de Desodorante "Axe" y "Glopopob Love" la autoridad no los sanciona sino que traslada este rol de de protección a los consumidores, y aquí es donde aparece el trabajo de los colectivos y entidades privadas que trabajan en representación y defensa de los derechos de aquellas poblaciones que son consideradas por la sociedad como vulnerables, entre la cuales está la mujer. Campañas como, por ejemplo, aquellas promovidas e impulsadas en su oportunidadporelColectivoFem-Tv ${ }^{25}$, integrado por el Centro de la Mujer Peruana Flora Tristán, el Colectivo Radial Feminista, el Movimiento Manuela Ramos, Demus y la Asociación de Comunicadores Calandria, donde hacen merecedor a la entrega del Premio Fem-Tv a la publicidad que mejor exprese el avance de las mujeres en la sociedad y promueva relaciones más equitativas entre hombres y mujeres; así como la entrega del antipremio Sapo-Tv, a la publicidad más machista y sexista difundida en los medios. También cabe mencionar la labor que actualmente desempeña el Consejo Nacional de Autorregulación Publicitaria CONAR, como entidad de índole privada para la autorregulación de la publicidad mediante la aplicación de su Código de Ética en materia publicitaria o la Sociedad de Radio y Televisión. Como podemos apreciar, la publicidad sexista si no es sancionada por el INDECOPI podrían ser retirados por la presión de algún colectivo, particular o entidad privada que inician campañas en contra y utilizan los medios de comunicación, incluso internet, las redes sociales, y por su repercusión obliga al anunciante a retirar el anuncio por miedo a que puedan perjudicar su marca. Si bien los casos en análisis se resolvieron cuando estaba vigente el Decreto Legislativo 691, el 26 de junio de 2008, se expidió el Decreto Legislativo 1044 - Ley de Represión de la Competencia Desleal, norma que unificó aquel Decreto Legislativo y el Decreto Ley $N^{\circ} 261221$, y por tal motivo, adicionalmente al tema propio de

24 Por ejemplo, es de conocimiento a nivel internacional que las campañas publicitarias del desodorante de la marca "Axe", el contenido de su publicidad ha causado mucha polémica y han sido calificados de machistas y de usar a la mujer como objeto sexual Ver: http:/www.marketingdirecto.com/actualidad/publicidad/axe-recibe-153-denuncias-por-publicidad-sexista-en-2003/; http://amula.pe/2011/09/06/polemico-comercial-de-axe-sobre-imagen-de-la-mujer/jackhurtado/ Consultado en junio de 2013

25 Ver : http://www.flora.org.pe/C_FemTv/FEMTV.htm Consultado en junio de 2013

Ver: http://www.observatorio.enfoquedeigualdad.org/noticias/12-notas/69-campana-contra-la-publicidad-sexista-en-peru . Consultado en junio de 2013

Ver:http://www.flora.org.pe/web2/index.php?option=com_content\&view=article\&id=417:premio-fem-tv-2011-a-lapublicidad-\&catid=40:redes\&Itemid $=100$ Consultado en junio de 2013. 
la competencia desleal, dicha norma también contiene disposiciones referentes a la difusión de la publicidad comercial.
En tal sentido, la normatividad actual que regula la publicidad en el Perú, señala lo siguiente:

\begin{abstract}
\begin{tabular}{|l} 
Decreto Legislativo 1044 (Vigente) \\
Artículo $17^{\circ}$.- Actos contra el principio de
\end{tabular} legalidad.-

17.1.- Consisten en la difusión de publicidad que no respete las normas imperativas del ordenamiento jurídico que se aplican a la actividad publicitaria.

17.2.- Constituye una inobservancia de este principio el incumplimiento de cualquier disposición sectorial que regule la realización de la actividad publicitaria respecto de su contenido, difusión o alcance.
\end{abstract}

Artículo $18^{\circ}$.- Actos contra el principio de adecuación social.-

Consisten en la difusión de publicidad que tenga por efecto:

a) Inducir a los destinatarios del mensaje publicitario

a cometer un acto ilegal o un acto de discriminación

$\mathrm{u}$ ofensa por motivo de origen, raza, sexo, idioma,

religión, opinión, condición económica o de cualquier otra índole;

b) Promocionar servicios de contenido erótico a un público distinto al adulto. La difusión de este tipo de publicidad solamente está permitida en prensa escrita de circulación restringida para adultos y, en el caso de radio y/o televisión, dentro del horario de una (1:00) a cinco $(5: 00)$ horas

Artículo $21^{\circ}$.- Interpretación de la publicidad.21.1.- La publicidad es evaluada por la autoridad teniendo en cuenta que es un instrumento para promover en el destinatario de su mensaje, de forma directa o indirecta, la contratación o el consumo de bienes o servicios.

21.2.- Dicha evaluación se realiza sobre todo el contenido de un anuncio, incluyendo las palabras y los números, hablados y escritos, las presentaciones visuales, musicales y efectos sonoros, considerando que el destinatario de la publicidad realiza un análisis integral y superficial de cada anuncio publicitario que percibe. En el caso de campañas publicitarias, éstas son analizadas en su conjunto, considerando las particularidades de los anuncios que las conforman.

\section{Decreto Legislativo 1044 (Vigente)}

Artículo $20^{\circ}$.- Uso de licencias publicitarias. En el ejercicio de la actividad publicitaria se encuentra permitido el uso del humor, la fantasía y la exageración, en la medida en que tales recursos no configuren actos de competencia desleal.
Decreto Legislativo 691 (Derogado)

"Artículo 3.- Los anuncios deben respetar la Constitución y las leyes. (...)"

Artículo 3.- “(...) Ningún anuncio debe favorecer o estimular cualquier clase de ofensa o discriminación racial, sexual, social, política o religiosa. Los anuncios no deben contener nada que pueda inducir a actividades antisociales, criminales o ilegales o que parezca apoyar, enaltecer o estimular tales actividades."
Artículo $\mathbf{2}^{\mathbf{0}}$.- Las normas deben interpretarse y aplicarse de buena fe, en armonía con los principios de la ética o deontología publicitaria generalmente aceptados.

Los anuncios deben ser juzgados teniendo en cuenta el hecho que el consumidor queda influenciado mediante un examen superficial del mensaje publicitario.

Las normas se aplican a todo el contenido de un anuncio, incluyendo las palabras y los números, hablados y escritos, las presentaciones visuales, musicales y efectos sonoros. 
De la comparación entre la normatividad vigente y la derogada podemos señalar que en ambas está presente el cumplimiento del Principio de Legalidad; sin embargo, en el Decreto Legislativo 691 en sus alcances, hacían mención al respeto a la Constitución y por lo tanto, se entendía que también implicaba la protección a los derechos fundamentales de la persona; a diferencia del actual Decreto Legislativo 1044 que hace referencia sólo al cumplimiento y vulneración de las normas propias de la actividad publicitaria.

Asimismo, el Decreto Legislativo 1044 ya no hace referencia a que las normas deben interpretarse y aplicarse en armonía con la ética o deontología publicitaria (previsto en su artículo $2^{\circ}$ ) sino que el artículo 21 del actual Decreto Legislación 1044 -Ley de Represión de la Competencia Desleal-, establece que la publicidad está orientada para la contratación o el consumo de bienes y servicios.

De igual modo, en el artículo 18 del Decreto Legislativo 1044 literal a) se introduce el denominado Principio de Adecuación Social $y$ establece que son actos contrarios a este Principio solo aquellos que tengan por efecto inducir a los destinatarios del mensaje publicitario a cometer un acto ilegal un acto de discriminación u ofensa. Es decir, que no basta la sola exposición de la publicidad sino que esta debe de provocar, causar en la realidad una conducta que configure un acto ilegal o un acto de discriminación y ofensa, que induzca de manera efectiva a su realización.

Esta precisión del vigente Decreto Legislativo 1044 a diferencia del derogado Decreto Legislativo 691, elimina cualquier alusión a la posibilidad de que se pueda sancionar aquella publicidad en que se muestre como algo tolerable una conducta contraria, enfatizando que el aparato administrativo represivo se pondrá en marcha solo en caso exista una prueba clara de que el anuncio motiva que los consumidores alteren su comportamiento y adopten una conducta contraria. (Ver Resolución 1857-2012/SC1-INDECOPI)

Así, el referido texto reconoce esta evolución legislativa y señala que el actual texto de la ley "(...) se propone, en atención a evitar restriccionesala libertad de expresión comercial, eliminar toda posibilidad de aplicar criterios de evaluación subjetivos en el enjuiciamiento de las conductas investigadas"; agregándose más adelante que "(...) el Decreto Legislativo $N^{\circ} 691$ establecía prohibiciones similares en su artículo 3; sin embargo, estas adolecían de poca claridad y objetividad, pues tenían un componente significativamente estimativo y no estandarizado que complicaba su aplicación por parte de la autoridad competente. Dicha situación ha sido corregida en el Decreto Legislativo al establecer claramente que se prohíbe la publicidad que tenga por efecto inducir a la comisión, en la realidad, de actos ilegales, de discriminación y de ofensa, eliminando la referencia a "actos antisociales" $y$ "criminales", así como al enaltecimiento $y$ estímulo de dichos actos que contempla la legislación precedente." (Ver Resolución 1857-2012/SC1-INDECOPI)

En ese sentido, solo será ilícito un anuncio publicitario cuando transmita un mensaje que objetivamente induzca a los destinatarios a cometer o reproducir en la vida cotidiana una práctica ilegal, es decir, una conducta que se encuentre expresamente proscrita por el ordenamiento jurídico. Lo cual, consistiría en que luego de visualizar la publicidad el consumidor adopte la decisión de llevar a cabo la misma conducta que se le expone en el anuncio ${ }^{26}$.

Por lo tanto, el solo hecho que un anuncio contenga alguna secuencia que, vista aisladamente, reproduce una escena ilegal $\mathrm{u}$ ofensiva, no resulta elemento suficiente para calificar como ilícita la pieza publicitaria, puesto que lo sancionable es que, visto en su integridad, se transmita un mensaje que

26 Debe precisarse que dicho criterio ha sido establecido, entre otras, en las Resoluciones 1557-2008/TDC-INDECOPI del 5 de agosto de 2008, 1736-2008/TDC-INDECOPI del 27 de agosto de 2008, 1800-2008/TDC-INDECOPI del 4 de septiembre de 2008; y, Resolución 0079-2009/SC1-INDECOPI del 2 de marzo de 2009. 
incentive una conducta ilegal en la vida cotidiana. Sin embargo, si bien sabemos que la publicidad genera o propicia conductas, modelos a seguir, etc., no se entiende la razón por qué el INDECOPI podría considerar que un comercial que presenta una escena lesiva a una persona, no es per se ilegal y que habría que demostrar que genera en el mundo real conductas ofensivas y discriminatorias.

Por otro lado, el humor la fantasía y la exageración, son recursos utilizados en publicidad y según el Decreto Supremo $N^{\circ}$ 20-94-ITINCI (hoy derogado), señalaba que aquellos podían emplearse en la medida que no debían implicar un engaño para el consumidor ni tampoco podían constituir infracción a las normas de publicidad; por lo tanto, vemos que esta regulación comprendía también la protección a los derechos fundamentales de las personas por la posible infracción a las normas constitucionales las mismas que debían ser respetadas por la actividad publicitaria y estaban mencionadas en el artículo $3^{\circ}$ del Decreto Legislativo 691. Sin embargo, el actual Decreto Legislativo 1044 en su artículo $20^{\circ}$ no lo contempla restringiendo la protección en la medida que el humor la fantasía y la exageración no configura actos de competencia desleal. Vemos pues que en la actual legislación hay una clara preocupación y preferencia por la defensa de los intereses del mercado en vez de la protección de la persona. Con la legislación actual, INDECOPI interpreta el uso de la fantasía, el humor y la exageración como elementos que influyen en la interpretación del anuncio y que contribuyen a recrear una situación irónica alejada de la realidad, bajo la cual el consumidor captaría el mensaje publicitario en forma exagerada, sin atribuir seriedad a las escenas o frases mostradas ${ }^{27}$. Por tanto, la utilización de estas licencias, por lo general, generaría -según dicha entidad- que los destinatarios de la pieza publicitaria no tomen en serio las diversas imágenes, secuencias y frases, de manera tal que el mensaje publicitario no tenga la aptitud de inducir efectivamente a brindar un trato cruel, degradante $\mathrm{u}$ ofensivo contra cierto sector vulnerable de la sociedad. ${ }^{28}$

Si los casos bajo exposición hubieran sido resueltos bajoelactual Decreto Legislativo 1044 , consideramos que las denuncias interpuestas a la publicidad de AXE y GLOBOPOP LOVE hubieran tenido el mismo resultado; y en el caso Directv (cuya decisión de la Comisión compartimos) hubiera sido resuelto no bajo el criterio de defender la dignidad de la mujer y su rol en la sociedad sino que hubiera sido declarado infundado aplicando el literal b) del artículo $18^{\circ}$ Actos contra el principio de adecuación social. b) Promocionar servicios de contenido erótico a un público distinto al adulto. La difusión de este tipo de publicidad solamente está permitida en prensa escrita de circulación restringida para adultos $y$, en el caso de radio y/o televisión, dentro del horario de una (1:00) a cinco (5:00) horas.

La autoridad administrativa, con la actual legislación en materia de publicidad, no está facultada en defender a la persona de aquella publicidad considerada "sexista" en la medida que no genere en la realidad una conducta ilegal, de discriminación u ofensa. La publicidad de carácter sexista lamentablemente incentiva la diferencia y estereotipos contra la mujer y no ayuda a crear y construir un pensamiento de respeto e igualdad entre ambos géneros (varón y mujer). Más aún, se permite que este tipo de publicidad se camufle bajo la visión del humor y la fantasía pero cuyo argumento central es realmente machista, discriminatorio y ofensivo para cualquier mujer. Para la autoridad administrativa

\footnotetext{
$27 \mathrm{Al}$ respecto el profesor español Tato Plaza señala que: "A veces, para poder captar mejor la atención del consumidor, las empresas anunciantes presentan su publicidad en forma humorística, utilizando para esto la ironía, el chiste o la sátira. Con respecto a estas expresiones publicitarias humorísticas, la doctrina reclamó siempre un trato benevolente. Esta petición se basaba en el convencimiento de que las frases publicitarias humorísticas, irónicas y satíricas suelen ser interpretadas por el público como exageraciones; los consumidores no toman en serio los anuncios que presentan un tinte humorístico, sino que al contemplarlos se limitan a sonreír y no les otorgan crédito ninguno". Véase: Tato Plaza, Anxo. La Publicidad Comparativa. Madrid: Marcial Pons, 1996, pp. 37-38.

28 Debe precisarse que este criterio ha sido utilizado por la Sala en la Resolución 0096-2009/SC1-INDECOPI del 10 de marzo de 2009. ver fundamento jurídico 36 del referido pronunciamiento.
} 
gubernamental si no provoca una conducta ilegal en la vida real no es sancionable.

Es tiempo de fomentar una mirada crítica a la publicidad; que los publicistas y anunciantes tomen conciencia que su trabajo debe respetar los derechos de las personas a su dignidad y no discriminación si es que deseamos realmente una sociedad cuyos ciudadanos consideren la verdadera igualdad entre hombres y mujeres.

Finalmente, desterremos el pensamiento de la utilización mujer-objeto en la publicidad, recurso demasiado machista para promocionar productos y servicios en el mercado; es necesario el cambio de mentalidad de los publicistas en apostar por la creación de anuncios publicitarios que realcen lo mejor de las personas en condición de igualdad, respeto y valores, es ahí donde la creatividad debe ser reconocida y recordada por los consumidores. En ese sentido, coincidimos con Balaguer quien señala lo siguiente: "La superación del modelo publicitario exige condiciones relativamente distintas de las medidas usuales de acción positiva en las mujeres para conseguir la igualdad. No basta con crear las condiciones de igualdad, sino que previamente es necesario decodificar activamente el mensaje publicitario, y sobre él construir nuevos modelos activos de mujer, que consigan centralidad, protagonismo, destruir el modelo-objeto para convertir a la mujer en verdadero sujeto." 29

\section{CONCLUSIONES}

La resolución del caso "Directv" representó un cambio de criterio de interpretación del entonces vigente artículo $3^{\circ}$ del Decreto Legislativo 691. El precedente que imperaba en ese entonces interpretaba la frase "favorecer" o "estimular" determinados tipo de discriminaciones $y$ ofensas como sancionables en la medida que el anuncio podría generar en el mundo real dichas conductas ofensivas o discriminatorias; sin embargo la interpretación de dicho artículo para el caso "Directv" la frase "favorecer" o "estimular" una ofensa o conducta discriminante adquiere una dimensión distinta, toda vez que reside en la necesidad de proteger directamente a las personas como sujetos de derecho, al exigirse que no se debe de favorecer o estimular cualquier atentado contra su dignidad a través de conductas ofensivas o discriminantes que se puedan mostrar en un anuncio publicitario.

La aplicación del argumento del uso del humor y la fantasía en la publicidad de Desodorante "Axe" y "Globopop Love", permitieron que actos ofensivos contra la dignidad de la mujer no hayan merecido sanción alguna por parte de la autoridad administrativa la misma que consideró mejor defender los derechos de las empresas en el mercado dejando a los consumidores y organizaciones civiles la potestad de censurar este tipo de publicidad.

Con la actual legislación en materia de publicidad comercial, la autoridad administrativa no está facultada en defender a las personas de aquella publicidad considerada "sexista", en la medida que ya no se encuentra regulada la prohibición con los términos "favorecer" o "estimular" sino que emplea la frase "inducir" a los destinatarios del mensaje publicitario a cometer un acto ilegal o un acto de discriminación u ofensa; por tal motivo, en la medida que no genere en la realidad una conducta ilegal $u$ ofensiva no será sancionado por INDECOPI trasladando este rol de protección de la persona y sus derechos fundamentales a entidades privadas y colectivos para su correspondiente sanción por la vulneración a las normas éticas de la publicidad comercial.

29 Balaguer, María Luisa (2008) Género y Regulación de la Publicidad en el ordenamiento jurídico. En: Revista Latina de Comunicación Social, (en línea) Vol. 11, Núm. 63, p. 28. Disponible en < http://redalyc.uaemex.mx/pdf/819/81912006031. pdf $>$ 51. Consultado en junio de 2013. 


\section{REFERENCIAS}

Balaguer, María Luisa (2008) Género y Regulación de la Publicidad en el Ordenamiento Jurídico. Revista Latina de Comunicación Social. Vol. 11, Núm. 63. (on line) Disponible en Internet: http:// redalyc.uaemex.mx/pdf/819/81912006031.pdf> 51. Consultado en junio de 2013.

Del Moral Perez, E (2000) "Los nuevos modelos de mujer y de hombre a través de la publicidad" En Comunicar N 14 pp. 208-217.

Duran, Julio. Ver Debates Jurídicos - 12/10/08: Publicidad Sexista En: http://www.derecho. usmp.edu.pe/centro_derecho_competencia/frame_actividades_debate04.html. Consultado en junio de 2013

Gonzalez Lobo, María Ángeles (1994). Curso de publicidad. Madrid: Editorial Eresma y Celeste.

Mock Ferreyros, Francisco Javier (2007) En: Publicidad Discriminatoria en razón de género. Quiebre del principio de predictibilidad de las resoluciones administrativas para incorporar nuevo criterio jurisprudencial en defensa de los derechos humanos. (on line) Disponible en Internet: http://www.glsabogados.com/pdf/Publicidad\%20Discriminatoria\%20en\%20Razon\%20de\%20 Genero.pdf www.glsabogados.com Consultado en junio de 2013.

Ortega Enrique (1977). La comunicación publicitaria. Madrid: Editorial Pirámide.

Royo Vela, M; Miquel Roero, M.J; Caplliure Giner, E. M. (2002) "La publicidad como reflejo de la realidad social: un análisis descriptivo de los roles de género y sexismo en la publicidad en revistas en el último año del siglo XX”. En Arxius N6, pp. 165-191.

Santaella López, Manuel (1982). Introducción al derecho de la publicidad. Madrid: Civitas.

Santiso Sanz, Raquel (2001) Las Mujeres en la publicidad: Análisis, Legislación y aportaciones para un cambio. (en línea) Disponible en <dialnet.unirioja.es/servlet/fichero articulo?codigo $=170282 \&$ orden... $>$ Consultado en junio de 2013

Tato Plaza, Anxo (1996) La Publicidad Comparativa. Madrid: Marcial Pons.

Catecismo de la Iglesia Católica,

Ver:http://www.vatican.va/roman_curia/congregations/cfaith/cti_documents/rc_cti_1983_dignitadiritti_sp.html. Consultado en junio de 2013

Constitución Política del Perú - 1993

Convención para la eliminación de todas las formas de discriminación contra las mujeres (CEDAW) Disponible en Internet: http://www.unicef.org/panama/spanish/MujeresCo_web.pdf Consultado en junio de 2013.

Código de Ética del Consejo Nacional de Autorregulación Publicitaria - CONAR Disponible en Internet: http://conarperu.org/web/codigos-/codigo-de-etica.html Consultado en junio de 2013.

Decreto Legislativo $N^{\circ}$ 691- Normas de Publicidad en Defensa del Consumidor, publicado el 6 de noviembre de 1991, en el Diario Oficial "El Peruano". 
D.S. $N^{\circ}$ 20-94-ITINCI Reglamento de la Ley de Normas de la Publicidad en Defensa del Consumidor, publicado el 14 de octubre de 1994, en el Diario Oficial "El Peruano".

Decreto Legislativo 1044 Ley de Represión contra la Competencia Desleal, publicado el 26 junio de 2008, en el Diario Oficial "El Peruano".

Resolución 283-97/TDC-INDECOPI del 28 de noviembre de 1997.

Resolución 0220-1998/TDC-INDECOPI del 19 de agosto de 1998.

Resolución 0333-1999/TDC-INDECOPI del 29 de septiembre de 1999.

Resolución 0360-1999/TDCINDECOPI del 20 de octubre de 1999.

Resolución N 163-2006/CCD-INDECOPI; del 18 de octubre de 2006.

Resolución Nº 205-2007/CCD-INDECOPI del 14 de noviembre de 2007.

Resolución 2346-2007/TDC-INDECOPI del 26 de noviembre de 2007.

Resolución 1557-2008/TDC-INDECOPI del 5 de agosto de 2008.

Resolución1736-2008/TDC-INDECOPI del 27 de agosto de 2008.

Resolución 1800-2008/TDC-INDECOPI del 4 de septiembre de 2008.

Resolución N 185-2008/CCD-INDECOPI del 19 de noviembre de 2008.

Resolución 0079-2009/SC1-INDECOPI del 2 de marzo de 2009.

Resolución 0096-2009/SC1-INDECOPI del 10 de marzo de 2009. 